\title{
Iranian EFL Teachers' Attitudes towards Lesson Planning based on their Gender
}

\author{
Mina Heidari \\ Department of English language Teaching, Ilam Branch,Islamic Azad University, Ilam, Iran \\ Akbar Azizifar (Corresponding author) \\ Department of English language Teaching, Ilam Branch,Islamic Azad University, Ilam, Iran \\ E-mail: Akb1354@yahoo.com \\ Habib Gowhary \\ Department of English language Teaching, Ilam Branch,Islamic Azad University, Ilam, Iran \\ Zahra Abbasi \\ Department of English language Teaching, Ilam Branch,Islamic Azad University, Ilam, Iran
}

Doi:10.7575/aiac.alls.v.6n.4p.80

URL: http://dx.doi.org/10.7575/aiac.alls.v.6n.4p.80
Received: $18 / 03 / 2015$

Accepted: 29/05/2015

\begin{abstract}
The purpose of this study was to examine Iranian EFL teachers' attitudes towards lesson plan based on their gender. The research is a quantitative study in which the data is obtained to get a great understanding on the relationship between lesson plan of Iranian English as Foreign Language (EFL) teachers and teachers' gender. The population included 93 teachers in Eyvan and Ilam, Iran high schools and institutes. Participants in this study answered a Modified Questionnaire, adopted from Ramaila et al (2014). Independent sample t-test was computed to determine the difference between teachers' attitudes towards lesson plan and their gender. Through statistically analysis it was found that, the female teachers were more interested in use of lesson plan than the male teachers. This paper recommends that more seminars workshops and in-service courses be organized for all science teachers to help train and boost their attitudes on the significance of lesson plans in teaching/learning of English in schools.
\end{abstract}

Keywords: Teachers’ Attitudes; Lesson Plan; Gender; Iranian EFL

\section{Introduction}

Lesson planning is an effective way for increasing the quality of education. Lesson planning is a process for defining the goals and understanding the needs, specifying available tools and possible limitations. According to Asfaw (2002), planning is the primary step of teaching \& learning employed in the class \& also organizes some activities for the class. So lesson plan seems to be helpful for a teacher to present the materials effectively. On the other hand, lack of a welldefine lesson plan may result a more problematic atmosphere for a teacher \& consequently less beneficial achievement outcomes. Saberian and Salemi (2002), defined lesson plan as a process for the determination of appropriate educational goals and diagnosis of issues, needs, facilities, and limitations which are on the way of reaching educational goals. Having appropriate curriculum and lesson plan, creates a lively and active atmosphere in the class and encourage students to participate in the process of learning-teaching. Ghazi and Fallahi (2011) argued that lesson plan is the written description of the learning process in which it is shown what, how, when, and where should be learned and is evaluated. According to Steinert (2005) planning training courses are based on learner needs and training is based on lesson plan lead to effectiveness of training courses.

Harmer (2007), viewed a lesson plan as a teaching preparation developed based on the teacher's thought about what will be suitable for the students and on what the curriculum or the syllabus expects them to do. As asserted by Richards and Bohlke (2011), "planning a lesson before teaching is considered essential in order to teach an effective lesson" (p.35). According to van der Walt (1990:30-36) the teacher should plan the materials in the syllabus in a way that will reflect his/her own theories about language learning \& teaching. A well-developed plan reflects the interests $\&$ needs of students. The lesson plan correlates with the teacher's philosophy of education, which is what the teacher feels is the purpose of educating the students (Boston et al 1999). A lesson plan must correlate with the text book the class uses. The school usually selects the text books or provides teachers with a limited text book choice for a particular unit the teacher must take great care \& select the most appropriate book for the students (Boston et al 1999).

Format of a lesson plan based on Brown (2001) theory:

1) Goal(s) : to define your purpose which you try to accomplish by the end of the class and it is may be generalized

2) Objectives : to relate explicitly what you ask your students to achieve, This is helpful for you to: 
a) Be sure that you actually are aware of what you want to do in the class

b) Preserve the unity of the lesson

c) Predetermine whether or not you are trying to accomplish too much

d) Assess learners' achievement after the lesson.

3) Materials and equipment: listing materials and equipment required for teaching is considered to be of a great significance while designing a good plan.

4) Procedures : it includes :

a) Warm-up activities e.g.an opening expression

b) Set of activities \& techniques in which you have determined appropriate periods of time for

I. Whole-class work

II. Small-group work

III. Teacher talk

IV. Student talk

c) Closure.

5) Evaluation: it is an assessment, formal or informal, that you make after students have enough opportunities for learning \& with no evaluation you can't assess your students' achievement and adjust your lesson plan for the future.

6) Extra-Class Work: it is sometimes misnamed "homework", but is defined as applications or extensions of classroom activity found by teacher aiding the students do some learning after the class (Brown, 2001). In very basic terms: a lesson plan is the teacher's guide for running a particular lesson, and it includes the goal (what the students are supposed to learn), how the goal will be reached (the method, procedure) and a way of measuring how well the goal was reached (test, worksheet, homework, etc.)

A review of existing literature on lesson plan suggested a need for further research in this field. The research on lesson planning in Iranian context seems to be inadequate and researchers have recently started its investigation. Although, some of the previous studies explored teacher's attitude towards lesson plan in different context. The previous related literature review indicated that many studies conducted on university professors and few studies included secondary school, high school or institution. The current study conducted on secondary school, high school or institution teachers. This study aims to replicate the same survey in a different context (Ilam) based on their gender.

\subsection{Research Question}

This study aimed to explore the following research question:

Is there any significant relationship between teachers' attitudes towards lesson planning and their gender?

\subsection{Research Hypothesis}

There is a significant relationship between teachers' attitudes towards lesson planning and their gender.

\section{Methodology}

\subsection{Participants}

The participants in this study were 93 EFL teachers from high schools and institutes in Eyvan in the province of Ilam and city of Ilam- west of Iran, 53 of whom were female and 40 were male. Selection was done from all available professional experienced teachers having university education. Table 1 shows the characteristic of participants according to their gender.

Table1. Frequency distribution of teachers by gender

\begin{tabular}{llll}
\hline & Number & Gender & \\
\hline Teachers & 93 & Female & Male \\
& & 53 & 40 \\
\hline
\end{tabular}

\subsection{Instruments}

In the present study which is a Likert-type measure, a questionnaire was used to elicit information from participants. This questionnaire, developed by Ramaila and Ramnarian, consists of 29 items. The scale was answered as follows: 1strongly Disagree, 2- Disagree, 3- Uncertain, 4- Agree and 5- Strongly Agree. Total score of the answerers showed the extent to which they agreed with lesson planning. In this study, the reliability coefficient of questionnaire was computed by Cronbachs' alpha. The result indicated that reliability coefficient was 0.78 .

\subsection{Procedure}

In this study, for collecting the data, questionnaires in the form of papers and online (using email) were spread up to different English Language teachers. Collecting data started at November to December 2014. The probable needed time for filling out questionnaire was about 10 minutes. 


\subsection{Statistical procedure}

To compute teacher's scale score, the researcher entered each teacher's response from the items of questionnaire into an Excel file then the Excel file was uploaded into the Statistical Package for Social Sciences (SPSS). The scales scores were computed.

\section{Results}

To investigate teachers' attitudes towards lesson planning and their gender, independent sample t-test was used. This section presents the findings along with the discussion about teachers' views of lesson planning based on their gender.

Table 2. Mean and Standard deviation of teachers' attitudes towards lesson planning

\begin{tabular}{llllll}
\hline Group Statistics & \multicolumn{1}{c}{} & & & \\
\hline \multicolumn{1}{c}{ Gender } & & $\mathrm{N}$ & Mean & Std. Deviation & Std. Error Mean \\
\hline & Male & 40 & 97.2250 & 10.19926 & 1.61265 \\
\cline { 2 - 6 } $\begin{array}{l}\text { teachers' attitudes towards } \\
\text { lesson planning }\end{array}$ & Female & 53 & 102.3396 & 11.16475 & 1.53360 \\
\hline
\end{tabular}

As seen in Table 2 above, the means of two groups are very close and so are the standard deviations and standard error of means. Male group has a mean of 97.2250 with a standard deviation of 10.19926 and the mean for the female group is 102.3396 with standard deviation of 11.16475 . Therefore a small difference can be observed between the answers given by the two groups in terms of gender.

In order to test teachers' attitudes towards lesson planning according to their gender, T-test was used (see Table 3). In order to see if the difference between the means of the two groups was statistically significant or not. The results of using t-test is shown in Table 3 below.

Table 3. T-test for investigating the relationship between gender and teachers' attitudes towards lesson planning

\begin{tabular}{|c|c|c|c|c|c|c|c|c|c|}
\hline & \multicolumn{9}{|c|}{$\begin{array}{l}\text { Levene's Test } \\
\text { Equality of } \\
\text { Variances }\end{array}$} \\
\hline & & & & & & & & \multicolumn{2}{|c|}{$\begin{array}{l}\text { 95\% Confidence } \\
\text { Interval of the } \\
\text { Difference }\end{array}$} \\
\hline & $\mathrm{F}$ & Sig & $\mathrm{T}$ & $\mathrm{Df}$ & $\begin{array}{l}\text { Sig.(2- } \\
\text { tailed) }\end{array}$ & $\begin{array}{l}\text { Mean } \\
\text { Difference }\end{array}$ & $\begin{array}{l}\text { Std. Error } \\
\text { Difference }\end{array}$ & Lower & Upper \\
\hline $\begin{array}{l}\text { Equal variances } \\
\text { assumed }\end{array}$ & 1.509 & 0.223 & -2.269 & 91 & 0.02 & -5.11462 & 2.25398 & -9.59187 & -0.63737 \\
\hline $\begin{array}{l}\text { Equal variances } \\
\text { not assumed }\end{array}$ & & & -2.298 & 87.6 & 0.02 & -5.11462 & 2.22543 & -9.53744 & -0.69181 \\
\hline
\end{tabular}

According to the obtained results (Table 3) on "teachers' attitudes towards lesson planning" score used by male and female, it is seen that there is meaningful relationship between gender of participants and teachers' attitudes towards lesson planning, since the obtained $\mathrm{T}$ of respondents is -2.269 , and the level of significance is less than 0.05 , so this hypothesis is accepted and it can be concluded that there is a significant difference between teachers' views on Lesson Plan based on their gender.

\subsection{Discussion}

In this study the conceptual analysis of the results is reported. The goal of this study was to explore the teachers' attitudes towards lesson planning based on their gender.

The statistical results indicated that there is a significance difference between male, female and their views, so the second hypothesis was accepted. Females were more interested in lesson planning compared to males. The results were congruent to those of Taghipour (2013); Kamran \& Sharghi (2011) who found that gender played a key role in this field and female were more favored lesson planning. The results of Saberian et al. (2003) showed that both male and female professors, consider lesson planning a necessity. Of female professors, $29 \%$ believed that heavy workload and lack of knowledge about lesson planning are two main obstacles in this regard, and admitted that lesson planning did affect the quality of their classes. 


\section{Conclusion}

Because of the important role teachers play in an educational system, this present study explored English teachers' attitudes at high schools and institute towards use of lesson plan in the class based on their gender.

This result indicated that there is a significant difference between teachers' views according to their gender, and females were more interested in use of lesson plan compare to males. It sounds that since lesson plan provides the teacher a framework based on which the procedure of teaching is shaped, it will be beneficial for teaching experts to plan their lessons prior to enter the class. On the other hand, according to the views made by the participants, designing a wellstructured lesson plan helps the teacher manage time appropriately and make appropriate decisions during his/her teaching process.

Most of the teachers believed in the role of lesson planning in improving the quality of education. This paper recommends that more seminars workshops and in-service courses be organized for all science teachers to help train and boost their attitudes on the significance of lesson plans in teaching/learning of English in schools. Therefore, it is suggested that education development centers offer workshops on lesson plan actively and all the teachers be asked to participate in these workshops at least once. Moreover, all teachers must be asked to prepare lesson plans and use them in their education. Lesson plan committee is suggested to be made within education development centers. Teachers should take part in in-service educational courses in this regard.

The sample of the study was drawn from a small cities (Eyvan and Ilam); therefore, results may not be generalizable to the whole country. Also, the number of participants in all levels (secondary, high school and institution) was not equal. This issue may be affected the result. In this study, the instrument was limited to a questionnaire then future studies can employed other instrument such as interview. Next limitation can be sample size of this study which was 93 participants. Structural equation modeling or path analysis usually requires a large sample size (n $>200)$ to avoid unstable estimates in case of small samples (Klein, 2011).

In many of these studies, the effects of these thinking and beliefs on improving teaching process seem to be neglected to some extent. This existing gap in educational planning of related organizations calls for further researches on Iranian EFL teachers from different aspects of cognition, thinking and beliefs, so that results can be used to pave the way for adopting effective decision making, planning and consequently progress in teachers' practice,

\section{References}

Asfaw, A. (2002). Analysis of Lesson plan: The case of English teaching in Kafa Zone.Retrievedfrom:etd.aau.et/dspace/bitstream/123456789/.../Abebe\%20Asfaw.pdf

Brown, H.D. (2001). Teaching by principles. An interactive approach to language pedagogy. (Second edition). New York: Pearson Education

Ghazi, S.H., Fallahi, E. (2008). Evaluation of the conformity of confirmed syllabus in lesson plans of Lorestan medical University teachers in the year of 1387. Green Quarterly Journal of Medical Education - Special Education Proceedings of the tenth National Congress of Medical Sciences - Shiraz, p: 256 [Persian].

Harmer, J. (2007). The practice of English language teaching. (4th ed). Harlow: Pearson Education.

Kamran, A., \& Sharghi A. (2011). : Knowledge and Attitude of Academic Staffs of Ardabil University of Medical Sciences on Lesson Planning. Journal of Health and Hygiene, 2(4),31 - 39.

Kline, R. B. (2011). Principles and practice of structural equation modeling (3rd ed.). New York: Guilford Press.

Ramaila, S., \& Ramnarain, U. (2014). Lesson planning practices of South African Physical Sciences teachers in a new curriculum. South African Journal of Education. University of Johannesburg, Johannesburg, South Africa

Richards, J. C., \& Bohlke, D. (2011). Creating effective language lessons. New York: Cambridge University Press.

Saberian M, Salemi S. (2002) How to write a lesson plan? 2nd ed, 2002 salemi Pub Co, Tehran: 40. [Persian]

Saberian, M, Haji Aghajani, S, Ghorbani, R, et al (2003), Instructors' point of view about lesson planning, Semnan Medical University, 2002, Journal of Babol University of Medical Sciences, 5(2), 33-36.

Saberian, M., Aghajani,S., Ghorbani, R.,\& Malek, M. (2003). Medical faculty members' attitude on lesson planning Semnan University of Medical Sciences. Journal of Medical Education, 2(2).

Steinert, Y. (2005). Staff development for clinical teachers. The Clinical Teacher; 2(2),104-10.

Taghipour, M, (2013). English Teachers' Attitudes towards Lesson Planning. The Iranian EFL Journal, 9(6), 354-363.

Van der Walt, J. L. (1990). The role of the teacher in communicative language teaching. Journal for Language Teaching, 24(1), 28-40. 